\title{
KOMUNIKACIJA
}

\section{PINIGAI POLITIKOJE: JUNGTINIŲ AMERIKOS VALSTIJŲ IR EUROPOS ŠALIŲ POLITINIO FINANSAVIMO TENDENCIJŲ ANALIZĖ}

\author{
Arnas Aleksandravičius
}

Vilniaus universiteto Komunikacijos fakulteto

Mediju tyrimu laboratorijos doktorantas

Vilnius University Faculty of Communication

PhD Student at Media Research Lab

Sauletekio al. 9, LT-10222 Vilnius

El.paštas arnas.aleksandravicius@kf.stud.vu.lt

\section{Santrauka}

Straipsnyje apžvelgiamas Jungtiniu Amerikos Valstijų ir Europos šaliu politinio finansavimo teisinis reguliavimas ir analizuojami mokslo darbai, kuriuose tiriamas šiu šaliu politinis finansavimas. Straipsnio tikslas - išnagrinejus Jungtinèse Valstijose ir Europos valstybèse atliktus partiju ir politikų vykdomo lèšu rinkimo tyrimus, nustatyti pagrindines šiu tyrimų kryptis ir trūkstamu tyrimu temas. Tokios analizès aktualumas grindžiamas tuo, kad tyrimy analize padeda geriau suprasti politinio finansavimo situacija Jungtinèse Valstijose ir Europos valstybèse, nustatyti šia tema atliekamu tyrimu tendencijas bei nauju tyrimu poreiki. Be to, tokia analize ir susistemintas politinio finansavimo tyrimu tematikos pateikimas gali būti kaip pagrindas būsimiems politinio finansavimo tyrimams Jungtinèse Valstijose ar Europos valstybèse.

Politinio finansavimo teisinio reguliavimo apžvalga leidžia teigti, kad Jungtinèse Valstijose ir Europos šalyse galiojantys politinio finansavimo istatymai dažnai skiriasi, tačiau ir vienur, ir kitur daugeliu atveju yra 
sudarytos palankios sąlygos partijoms bei politikams rinkti lëšas iš rèméjų. Išanalizavus mokslinius tyrimus, išskirtos pagrindinès jų kryptys Jungtinese Valstijose ir Europoje. Nustatyta, kad politinio finansavimo tyrimy sritis, kurioje Europos šalys labiausiai atsilieka nuo Jungtiniu Valstiju, yra lèšu rinkimas iš individualiu aukotoju, ypač pasitelkiant interneta, kaip lèšu rinkimo komunikacijos priemonę. Pastebèta, kad trūksta tyrimu, kuriuose lèšu rinkimas būtų analizuojamas iš komunikacijos perspektyvos. Straipsnyje taip pat tiriamos partiju ir politiku galimybes pritraukti daugiau lèšu iš individualių aukotojų, ypač pasitelkiant interneto galimybes.

Reikšminiai žodžiai: politinis finansavimas; politinių kampanijų finansavimas; lèšu rinkimas; politinio finansavimo reguliavimas; politinių partijų rèmèjai; politinès partijos.

\section{Ivadas}

Finansiniai ištekliai nuo seno turi didelę reikšmę politikoje, nes daugiau lèšų valdanti politinè jèga gali sau leisti didesnès apimties rinkimų kampanijas ir brangiau kainuojančius agitacijos būdus. Anksčiausiais laikais plačios finansinès galimybès per rinkimus reiškė galią papirkti rinkejjus, kadangi neegzistavo ịstatymai, kurie tai draustų. Teigiama, kad ir George'as Washingtonas, pralaimèjęs pirmus rinkimus ị Virdžinijos atstovų rūmus 1755 metais, kituose rinkimuose 1757 metais savo rinkejjams pirko ir dovanojo romo, punšo, sidro, alaus ir tuos rinkimus laimejjo. Niujorke Bruklino rajono respublikonai 1876 metais gatvėmis vedžiojo du jaučius, vèliau tą pačią dieną juos paskerdè ir parke iškepè, o mėsą išdalijo susirinkusiems tūkstančiams rinkẻjų ${ }^{1}$. Daugelis politikų ịvairiose demokratinèse šalyse XIX amžiuje turèjo beveik

1 Bramen, Lisa. Swilling the Planters With Bumbo: When Booze Bought Elections, 2010. Prieiga per internetą: http://www.smithsonianmag.com/arts-culture/swillingthe-planters-with-bumbo-when-booze-bought-elections-102758236/?no-ist [žiūrèta 2016 m. spalio 2 d.]. 
neribotas galimybes rinkti lèšas ir jas leisti politiniams tikslams, tačiau XIX a. pabaigoje Jungtinèse Valstijose ir Jungtineje Karalystejje buvo priimti pirmieji tai varžantys ịstatymai.

Jungtinèse Valstijose 1883 metais priimtas Pendletono tarnautojų reformos įstatymas ${ }^{2}$ uždraudè politikams gauti lèšų mainais už valstybès tarnautojo darbo vietą, o 1907 metais buvo priimtas Tillmano aktas, neleidžiantis korporacijoms finansiškai remti kandidatų. 1939 metų Hatcho aktas uždraudė politikams naudoti valstybės lèšas per savo kampanijas, taip pat renkant lěšas rinkimų kampanijai už jas žadèti atsilyginti postais, paaukštinimais, sutartimis ir kitomis paslaugomis. Jungtinejje Karalystejje 1883 metais buvo priimtas Korupcijos ir nelegalios veiklos prevencijos aktas 3 , kuriame, priešingai nei Jungtinių Valstijų ìstatymuose, buvo orientuojamasi ne $\mathfrak{i}$ finansinès paramos politikams ribojimą, bet ị kandidatų išlaidų ribojimą. Garbės apdovanojimų (piktnaudžiavimo prevencijos) aktas ${ }^{4}$, Jungtinèje Karalystėje ịsigaliojęs 1926 metais, uždraudè politikams už pinigus pardavinèti titulus ir valstybès apdovanojimus.

Politinį finansavimą reguliuojantys ịstatymai ịvairiose šalyse leidžiami ir atnaujinami iki šiol, tačiau dar niekada lěšų rinkimas politikoje nevaidino tokio svarbaus vaidmens kaip XXI amžiuje. Chrisas W. Bonneau teigia, kad „lèšu rinkimas kampanijai, suteikdamas galimybę vienam kandidatui ir atimdamas ją iš kito, vaidina pagrindinị vaidmenį rinkimų procese “5. Davidas B. Magleby tvirtina, kad lèšų rinkimo ir jų išleidimo reikšmès bent jau tam tikrose valstijose „neįmanoma pervertinti“"6. Tai ypač aktualu prieš rinkimus, nes tiesiogiai

2 Angl. Pendleton Civil Service Reform Act.

3 Angl. Corrupt and Illegal Practices Prevention Act.

4 Angl. Honours (Prevention of Abuses) Act.

5 Bonneau, Chris W. Campaign Fundraising in State Supreme Court Elections. Social Science Quarterly. 2007, vol. 88, no. 1.

6 Magleby, David B. Rolling in the Dough: The Continued Surge in Individual Contributions to Presidential Candidates and Party Committees. All Faculty Publications, 2008, paper 198. 
lemia, kaip dažnai ir kaip efektyviai partija ar kandidatas gali pasiekti rinkejjus mokamais komunikacijos kanalais, kurių galimybės nuolat auga.

Didėjant lèšu ịtakai politikoje, tema tapo aktuali ir ịvairių sričių mokslininkams. Pirmieji mokslo darbai apie politinị finansavimą Jungtinèse Valstijose pasirodè dar XX a. pirmoje puseje, o Europoje temą rimtai tyrinèti imta tik praejjus dešimtmečiui po Antrojo pasaulinio karo. Šiandien tokių tyrimų daroma daug - analizuojamas ir išsivysčiusių, ir besivystančių šalių politinis finansavimas visuose žemynuose, daugelyje pasaulio šalių. Šiame straipsnyje politinio finansavimo tyrimai analizuojami atskirai, jie skirstomi $\mathfrak{i}$ dvi dalis - atliekamus Jungtinėse Valstijose ir atliekamus Europos valstybėse. Tyrimų skirstymas ị šias dvi grupes pasirinktas todèl, kad Jungtinių Valstijų politinio finansavimo sistema yra išskirtinè, o šioje šalyje per rinkimus surenkama ir išleidžiama daugiau lèšų nei bet kurioje kitoje pasaulio šalyje ${ }^{7}$. Be to, apie politini finansavimą Jungtinèse Valstijose parengta ypač daug mokslo darbų ir atliekama kur kas daugiau tyrimų nei kitose šalyse. Europoje lèšų rinkimas dar nèra tapęs kertiniu rinkimų kampanijos elementu ir politinio finansavimo tyrimų Europos šalyse pasitaiko mažiau.

Šiame straipsnyje analizuojama Jungtinių Valstijų ir Europos šalių partijų finansinio reguliavimo aplinka ir šiose valstybėse atlikti politinio finansavimo tyrimai. Straipsnio tikslas - išnagrinèjus Jungtinèse Valstijose ir Europos valstybėse atliktus partijų ir politikų vykdomo lèšų rinkimo tyrimus, nustatyti pagrindines šių tyrimų kryptis ir trūkstamų tyrimų temas. Tokia analizè reikalinga, nes ji padètų suprasti politinio finansavimo tyrimų tendencijas ịvairiose valstybèse, įvertinti politinị finansavimą reguliuojančių ịstatymų ịtaką Jungtinių Valstijų ir

7 Pavyzdžiui, 2016 m. Jungtinių Valstijų prezidento rinkimuose kandidatė Hillary Clinton iš viso surinko 1,4 milijardo dolerių, o rinkimus laimèjęs Donaldas Trumpas - 932 milijonus dolerių. Britų konservatoriai 2015 metais surinko 33,6 milijono svarų sterlingų, o leiboristai - 28,7 milijono. 
Europos valstybių politinių partijų galimybėms renkant lèšas. Taip pat tokia analizè ir susistemintas politinio finansavimo tyrimų tematikos pateikimas gali būti kaip pagrindas būsimiems politinio finansavimo tyrimams Jungtinèse Valstijose ar Europoje.

\section{Politinio finansavimo teisinio reguliavimo ypatumai Europoje ir Jungtinèse Amerikos Valstijose}

Tiek Europos valstybėse, tiek Jungtinèse Valstijose galiojantys ịstatymai numato galimybes partijoms ir politikams pritraukti lèšu ịvairiais būdais - gauti valstybès finansinę paramą, rinkti aukas iš rèmėjų ar rinkti narystės mokesčius. Vis dèlto įvairiose šalyse politinio finansavimo reguliavimas skiriasi. Šioje straipsnio dalyje analizuojami įvairių valstybių teisinio reguliavimo ypatumai, kurie daro ịtaką tų šalių politinių partijų ar kandidatų galimybėms rinkti lèšas.

Išskirtinis partijų finansavimo bruožas, būdingas Europos šalims, yra valstybès finansinè parama, teikiama partijoms. Pirmoji Europos šalis, ịteisinusi toki partijų finansavimą 1958 metais, buvo Vokietijos Federacinè Respublika. Vèliau šis finansavimo būdas ėmė sparčiai populiarèti, o 2014 metais vienintelè Europos Sąjungos šalis, neitteisinusi valstybès paramos politinèms partijoms, buvo Malta. 2015 metais ir Maltos parlamentas įteisino partijų finansavimą valstybės léšomis ${ }^{8}$. Svarbu paminèti, kad 2014 metais Italijos parlamente nutarta priešingai - laipsniškai atsisakyti valstybès finansavimo, kad būtų išvengta korupcijos panaudojant šias lěšas ${ }^{9}$. Partijų finansavimas valstybės lèšomis

8 Party financing: a lost opportunity. Malta Today, 2015. Prieiga per internetą: http://www.maltatoday.com.mt/comment/editorial/55378/party_financing_a_lost opportunity\#.WLW1kDvyg2w [žiūrèta 2016 m. spalio 3 d.].

9 Di Giorgio, Massimiliano; Scherer, Steve. Italy votes to phase out public financing of political parties. Reuters, 2014. Prieiga per internetą: http://www.reuters.com/ article/us-italy-politics-financing-idUSBREA1J1IL20140220 [žiūrèta 2016 m. spalio 3 d.]. 
šioje šalyje turètų būti galutinai panaikintas 2017 metų pabaigoje arba 2018 metais, nuo tada Italija bus vienintelè Europos Sąjungos valstybè, neteikianti partijoms lèšų.

Partijos, siekiančios gauti finansavimą iš valstybės, kiekvienoje šalyje turi atitikti savus nustatytus kriterijus. Dažniausiai kriterijai apibrěžiami tam tikru konkrečios partijos surinktu balsų skaičiumi arba surinktų balsų procentu nuo visų pastaruosiuose nacionaliniuose rinkimuose atiduotų balsų skaičiaus. Kitos galimos sąlygos - partija pastaruosiuose rinkimuose privalo būti iškovojusi tam tikrą skaičių vietų šalies parlamente, turèti tam tikrą skaičių narių arba būti surinkusi ne mažiau kaip tam tikrą procentą balsų kiekvienoje apygardoje, kurioje buvo iškèlusi kandidatą.

Jungtinès Karalystės partijos, pretenduojančios ị valstybès finansavimą, privalo turèti bent du narius Bendruomenių rūmuose. Valstybès lèšos paskirstomos proporcingai pagal gautus balsus ir laimètas vietas. Papildomą finansavimą gali gauti opozicijos partijos, jei jos iškovojo bent dvi vietas arba surinko daugiau nei 150 tūkst. balsų pastaruosiuose visuotiniuose rinkimuose ${ }^{10}$.

Vokietijoje valstybės finansavimo siekiančios partijos turi surinkti bent 0,5 proc. balsų rinkimuose ị Europos Parlamentą ir (ar) 1 proc. balsų nacionaliniuose rinkimuose arba 10 proc. balsų savo apygardoje. I valstybès paramą negali pretenduoti partijos, dalyvaujančios tik Europos Parlamento arba tik savivaldos rinkimuose. Partijos gauna tam tikrą sumą pinigų už kiekvieną gautą balsą pastaruosiuose rinkimuose i Europos Parlamentą arba Bundestagą. Už pirmus keturis milijonus balsų partija gauna 0,85 euro už balsą, o už likusius - 0,70 euro už balsą. Svarbus aspektas yra tas, kad bent pusė partijos pajamų privalo būti

${ }^{10}$ Van Klingeren, M. et al. Party Financing And Referendum Campaigns In Eu Member States. European Parliament, 2015. Prieiga per internetą: http://www.europarl. europa.eu/RegData/etudes/STUD/2015/519217/IPOL_STU(2015)519217_EN.pdf [žiūrèta 2016 m. spalio 3 d.]. 
surinkta iš kitų šaltinių ${ }^{11}$. Tai rodo, kad Vokietijoje yra skatinamas lèšų rinkimas iš rẻmèjų.

Prancūzijoje valstybès finansinę paramą gali gauti partijos, kurios surinko bent 1 proc. balsų 50-yje apygardų arba 1 proc. balsų visose apygardose, kuriose dalyvavo rinkimuose. Lèšos skiriamos proporcingai balsų, gautų pastaruosiuose parlamento rinkimuose, skaičiui, taip pat kasmet proporcingai parlamentarų, kurie deklaruoja esantys konkrečios partijos nariai, skaičiui. Be to, Prancūzijoje egzistuoja galimybè kandidatams atgauti iš valstybès lèšas, išleistas per rinkimų kampaniją ${ }^{12}$.

Lietuvoje valstybè irgi teikia dotacijas partijoms, $\mathfrak{i}$ jas gali pretenduoti daugiau nei 3 proc. rinkejų balsų pastaruosiuose rinkimuose surinkusios partijos, o pinigai skiriami atsižvelgiant i partijos gautų balsų skaičių. Per 2016 metus Lietuvos politinès partijos iš valstybės bendrai gavo 5,5 milijono eurų ${ }^{13}$.

Kitoks nei Europos valstybėse finansavimo, teikiamo dalyvaujantiems politikoje, modelis egzistuoja Jungtinèse Valstijose. Šioje šalyje valstybès finansavimas partijoms ir kandidatams gali būti skiriamas tik per prezidento rinkimus. Valstybès lèšos skiriamos trimis būdais: a) per pirminius rinkimus kandidatai gali gauti 250 dolerių už kiekvieną tokio paties dydžio ar didesnę auką, gautą iš rẻmėjų; b) valstybės lèšomis gali būti organizuojamos didžiųjų partijų nacionalinès konvencijos, kuriose renkami partijų kandidatai; c) valstybės lèšomis gali būti finansuojami konvencijose išrinktų parijų kandidatai ị prezidentus. Jungtinèse Valstijose svarbus rinkimų finansavimo valstybės lèšomis ypatumas yra tas, kad prièmę valstybès lèšas kandidatai įsipareigoja laikytis išlaidų limito. Pavyzdžiui, per 2016 metų rinkimus valstybès lèšas prièmę kandidatai ì prezidentus būtų negalèję išleisti daugiau

11 Ten pat.

12 Ten pat.

13 Valstybės biudžeto dotacijos ir dalies išlaidų politinei kampanijai kompensavimas. Vyriausioji rinkimų komisija, 2016. Prieiga per internetą: http:/www.vrk.1t/ valstybes-biudzeto-dotacijos-ir-dalies-islaidu-politinei-kampanijai-kompensavimas [žiūrèta $2016 \mathrm{~m}$. spalio $5 \mathrm{~d}$.]. 
kaip 48,07 milijono dolerių per pirminius rinkimus ir 96,14 milijono dolerių per pagrindinius rinkimus ${ }^{14}$.

Ivairių skirtumų galima pastebėti tarp tam tikrų Europos šalių ir Jungtinių Valstijų partijoms ir politikams įstatymo numatytų galimybių rinkti lëšas iš rèmejjų. Dažniausiai pasitaikantys skirtumai priklauso nuo to, ar egzistuoja limitai, kiek kandidatas ar partija gali gauti lèšų iš vieno asmens, ar gali gauti lèšų iš verslo įmonių arba užsienio. Dar vienas svarbus aspektas - ar egzistuoja limitai, kiek lèšų partija ar kandidatas iš viso gali surinkti iš visų rèmèjų ir kiek galima išleisti vienai rinkimų kampanijai.

Jungtinejje Karalystèje partijoms ir politikams aukoti gali kiekvienas asmuo, esantis šalies rinkejų sąraše, ar kiekviena šalyje registruota organizacija (įskaitant verslo įmones). Jungtinèje Karalystejje nèra jokių limitų, ribojančių aukojamų lèšų sumą. Partijos turi registruoti visas aukas, o apie dideles aukas pranešti šalies rinkimų komisijai (vèliau šie duomenys skelbiami internete, viešoje aukotojų duomenų bazèje $)^{15}$. Viršutinès išlaidų ribos - tai apribojimas, turintis didelę reikšmę partijų galimybėms rinkti lèšas Jungtinèje Karalystėje. Šie išlaidų limitai nustato, kiek daugiausia lèšų partijos gali išleisti konkretiems rinkimams. Jie kinta per kiekvienus rinkimus, be to, priklauso ir nuo partijos keliamų kandidatų skaičiaus.

Vokietijoje partijoms ir kandidatams yra sudarytos palankios sąlygos rinkti lèšas iš rèmejų. Vieninteliai apribojimai - lèšas aukoti draudžiama tik įmonėms, turinčioms sutarčių su vyriausybe, taip pat yra draudžiamos anoniminès aukos. Vokietijos ịstatymai nenumato limitų nei kiek lèšų partijai ar politikui gali paaukoti vienas žmogus, nei kiek lèšų iš viso galima surinkti iš rèmëjų. Neegzistuoja ir jokie išlaidų limitai - vienai kampanijai galima surinkti ir išleisti tiek lèšų, kiek pageidaujama.

${ }^{14}$ Quick Answers to Public Funding Questions. Federal Election Commission, n. d. Prieiga per internetą: http://www.fec.gov/ans/answers_public_funding.shtml [žiūrèta 2016 m. spalio 5 d.].

15 Donations and loans to political parties. The Electoral Commission, n. d. Prieiga per internetą: http://www.electoralcommission.org.uk/find-information-by-subject/ political-parties-campaigning-and-donations/donations-and-loans-to-politicalparties [žiūrèta 2016 m. lapkričio 14 d.]. 
Prancūzijoje egzistuoja griežtesni apribojimai - partijos ir politikai negali gauti lèšų nei iš juridinių asmenų, nei iš užsienio. Draudžiamos ir anoniminès aukos. Prancūzijoje irgi galioja apribojimas, leidžiantis vienam asmeniui paaukoti partijai ar politikui ne daugiau kaip 30000 eurų. Kitų lèšų rinkimo ar išlaidų limitų Prancūzijos įstatymai nenumato.

Lietuvoje galiojantys politinių lèšų rinkimo ịstatymai kelia rimtų suvaržymų partijų ir politikų galimybèms rinkti léšas. Asmuo vienam politinès kampanijos dalyviui gali paaukoti ne daugiau kaip 7570 eurų, o visi rèmejjai, aukojantys daugiau nei po 12 eurų, privalo deklaruoti turtą ir pajamas ${ }^{16}$. Taip pat Lietuvoje egzistuoja ir kandidatų bei partijų išlaidų limitai, apskaičiuojami pagal specialias formules. Pavyzdžiui, per 2016 metų Seimo rinkimus partijų sąrašai galèjo išleisti ne daugiau kaip 740 tūkst. eurų, o vienmandatèse iškelti kandidatai - nuo 19000 iki 22000 eurų, priklausomai nuo apygardos dydžio ${ }^{17}$.

Jungtinèse Valstijose įstatymai numato lèšu aukojimo limitus rèméjams - vienas asmuo per vienus rinkimus kandidatui gali paaukoti ne daugiau kaip 2700 dolerių. Verslo korporacijoms draudžiama tiesiogiai remti kandidatus. Kandidatų išlaidoms Jungtinėse Valstijose limitų nèra, išskyrus jau minètus atvejus, kai kandidatas priima valstybės finansavimą. Jokie limitai netaikomi nepriklausomų išlaidų politinio veiksmo komitetams - šios organizacijos gali neribotai, dažnai ir anonimiškai, rinkti lěšas tiek iš individualių rẻmejjų, tiek iš organizacijų (tarp jų ir iš verslo įmonių) ir surinktas lèšas išleisti agitacijai už kandidatą ar prieš ji.

Apibendrinant pasakytina, kad Europos šalių ir Jungtinių Valstijų teisinis politinio finansavimo reguliavimas turi ir skirtumų, ir panašumų. Europoje yra geriau išplètotos valstybės finansavimo tradicijos - ši

${ }^{16}$ Aukos. Vyriausioji rinkimų komisija, n. d. Prieiga per internetą: http://www.vrk.lt/ aukos-2016 [žiūrèta 2016 m. spalio 26 d.].

17 Nustatyti politinès kampanijos išlaidų limitai 2016 metams. Vyriausioji rinkimų komisija, 2016. Prieiga per internetą: http://www.vrk.lt/naujienos/-/content/10180/1/ nustatyti-politines-kampanijos-islaidu-limitai-2016-metams [žiūrèta $2016 \mathrm{~m}$. spalio 29 d.]. 
partijų finansavimo būdą taiko absoliuti dauguma žemyno šalių. Jungtinèse Valstijose valstybès finansavimas tampa iš esmès nereikalingas: nors jis gali būti skiriamas tik prezidento rinkimams, nuo 2012 metų né vienas didžiųjų partijų nominuotas kandidatas i prezidentus neprièmé valstybės lèšų. Dar vienas skirtumas - Europoje neegzistuoja Jungtinėms Valstijoms būdingi nepriklausomų išlaidų politinio veiksmo komitetai, suteikiantys galimybių kampanijos metu anonimiškai ir be apribojimų surinkti milžiniškas sumas pinigų ir jas išleisti. Vis dèlto Europos šalyse ir Jungtinèse Valstijose ịstatymų numatytos galimybès rinkti lèšas turi ir daug panašumų. Išlaidų limitai neegzistuoja ne tik Jungtinèse Valstijose, bet ir daugelyje Europos Sąjungos šalių: Vokietijoje, Prancūzijoje, Italijoje, Švedijoje, Danijoje, Nyderlanduose, Belgijoje, Airijoje, Čekijoje, Suomijoje, Estijoje, Maltoje, Kipre. Be to, Europos valstybėse galioja skirtingi ịstatymai, reguliuojantys, kiek daugiausia lěšų vienas asmuo gali paaukoti. Tokių limitų nėra Jungtinejje Karalysteje, Vokietijoje ir daugelyje kitų Europos Sąjungos valstybių.

Ivertinus Europos šalių ir Jungtinių Valstijų politinio finansavimo reglamentavimo ypatumus galima teigti, kad nors Jungtinèse Valstijose egzistuoja ilgametės sẻkmingo ir efektyvaus lèšų rinkimo tradicijos, daugelyje Europos šalių galiojantys politinių lèšų rinkimo ịstatymai taip pat sudaro palankias sąlygas partijoms ir politikams rinkti lèšas iš rèmejjų. Jungtinių Valstijų ir Europos šalių politinio finansavimo tyrimai analizuojami kitose dviejose šio straipsnio dalyse.

\section{Politinio finansavimo tyrimai Jungtinèse Amerikos Valstijose: ịstatymai, politinio veiksmo komitetai ir lèšų rinkimas iš individualių aukotojụ}

Pirmųjų Jungtinių Valstijų politinių kampanijų lèšas reguliuojančių ìstatymų atsiradimas ir didejjanti finansų įtaka politikai paskatino mokslininkus tyrinèti šią temą jau XX a. pradžioje. Pirmasis to èmèsi Jamesas K. Pollockas, 1926 metais jis nuodugniai ištyrè politinị 
finansavimą reguliuojančius įstatymus, politinėms kampanijoms surenkamų lèšų šaltinius, šių lěšų rinkimo metodus, valdymą ir kampanijų išlaidas Jungtinèse Valstijose ${ }^{18}$. Louise Overacker 1932 metais taip pat gvildeno šias temas ir lygino politinio finansavimo įstatymus Jungtinèse Valstijose ir kitose šalyse ${ }^{19}$. L. Overacker ịvertino darbininkų klasès indèlị i šalies politinių lèšų kaupimą ir nustatè, kad šis indèlis yra nedidelis ${ }^{20}$. Be to, ji tyré 1936 metų $^{21}, 1940$ metų $^{22}$ ir 1944 metų $^{23}$ prezidento rinkimų kampanijų finansavimą. Johnas W. Lederle analizavo politinių komitetų išlaidas prièmus Hatcho aktą ${ }^{24}$ ir partijų finansavimą per prezidento rinkimus ${ }^{25}$.

Šiuo laikotarpiu jau vyko ir mokslininkų diskusijos politinio finansavimo temomis, pavyzdžiui, 1928 metais George'as Lundbergas teigè, kad politinę korupciją nugalèti reikètų ne keičiant finansavimo isstatymus, bet atliekant šalies socialinę reorganizaciją, pritaikant savitą valdžios sistemą įvairiems regionams. Jis taip pat siūlè daugiau sprendimų prièmimo galių suteikti ekspertams, o ne masėms ${ }^{26}$. Carltonas G. Ketchumas 1938 metais rašè apie Respublikonų partijos pastangas

${ }_{18}$ Pollock, James K. Party Campaign Funds. A. A. Knopf. New York, 1926. 296 p.

${ }^{19}$ Overacker, Louise. Money in elections. The Macmillan company. New York, 1932. $476 \mathrm{p}$.

${ }^{20}$ Overacker, Louise. Labor's Political Contributions. Political Science Quarterly. 1939, vol. 54, no. 1, p. 56-68.

${ }^{21}$ Overacker, Louise. Campaign Funds in the Presidential Election of 1936. American Political Science Review. 1937, vol. 31, p. 473-498.

${ }^{22}$ Overacker, Louise. Campaign Finance in the Presidential Election of 1940. The American Political Science Review. 1941, vol. 35, no. 4, p. 701-727.

${ }^{23}$ Overacker, Louise. American Government and Politics: Presidential Campaign Funds, 1944. The American Political Science Review. 1945, vol. 39, no. 5, p. 899925.

${ }^{24}$ Lederle, John W. Political Committee Expenditures and the Hatch Act. Michigan Law Review. 1945, vol. 44, no. 2, p. 294-299.

${ }^{25}$ Lederle, John W. Party Finance in a Presidential Election Year. The Annals of the American Academy of Political and Social Science. 1948, vol. 259, Parties and Politics: 1948, p. 64-74.

${ }^{26}$ Lundberg, George. Campaign Expenditures and Election Results. Social Forces. 1928, vol. 6 , no. 3 . 
atsiriboti nuo kelių didžiųjų rėmèjų, siekiant gauti lěšų iš kuo daugiau ìvairių donorų, kad taip būtų užtikrinamas skaidrumas, ir siūle šị lèšų pritraukimo modelį taikyti ir kitiems politikos dalyviams ${ }^{27}$.

Nuo XX a. vidurio politinị finansavimą Jungtinèse Valstijose èmé tyrinèti ịvairių sričių mokslininkai. Kalbant apie šio laikotarpio tyrimus, ypač svarbu išskirti Alexanderio Heardo ir Herberto E. Alexanderio darbus. A. Heardas atliko itin plataus masto politinio finansavimo Jungtinèse Valstijose analizę - jis tyrė pinigų reikšmę politikai, politinėms kampanijoms aukojančių asmenų motyvus, politikų surenkamų lèšų šaltinius, lèšu rinkimo būdus, lèšu rinkimo įtaką valdžiai ir politinių kampanijų išlaidas ${ }^{28}$. O H. E. Alexanderis atskirose knygose aprašè ištirtus visus Jungtinių Valstijų prezidento rinkimus nuo 1960 iki 1992 metų, jis atskirai tyrinèjo visų kandidatų finansinę aplinką prieš nominaciją ir po jos, kandidatų lèšų rinkimo būdus, kandidatų rinkimų ir ne rinkimų ${ }^{29}$ išlaidas, partijų suvažiavimų išlaidas, politinio veiksmo komitetų $^{30}$ ittaką ir kitus finansinius konkrečių rinkimų aspektus. Be to, H. E. Alexanderis tyrè kampanijų finansavimą įvairiose valstijose ir įstatymų įtaką politiniam finansavimui. Iš viso politinio finansavimo tema jis paraše 20 knygų ir daugiau kaip 200 monografijų bei straipsnių ${ }^{31}$.

Išanalizavus XX a. antroje puseje ir XXI a. pradžioje atliktus mokslinius tyrimus, kuriuose nagrinėjamas politinis finansavimas Jungtinèse Valstijose, galima išskirti tris pagrindines šių tyrimų kryptis:

${ }^{27}$ Ketchum, Carlton G. Political financing, 1937 model. Public Opinion Quarterly. 1938, vol. 2, no. 1, p. 135-140.

${ }^{28}$ Heard, Alexander. The Costs of Democracy. Chapel Hill: University of North Carolina Press, 1960.

${ }^{29}$ Rinkimų (,,hard money“) lèšų panaudojimą griežtai reguliuoja įstatymai, o ne rinkimų (,soft money“) lèšos, skirtos su rinkimais tiesiogiai nesusijusioms partijos reikmėms, įstatymo nekontroliuojamos.

${ }^{30}$ Angl. Political Action Committee (PAC) - tai organizacija, renkanti pinigus iš savo narių ir leidžianti tuos pinigus rinkimų tikslais.

${ }^{31}$ Cornette, Gloria; Herbert, E. Alexander. The Campaign Finance Institute, n. d. Prieiga per internetą: http://www.cfinst.org/HerbertEAlexander/Bio.aspx [žiūrèta 2016 m. lapkričio 8 d.]. 
1. Politinị finansavimą ir lèšų rinkimą reguliuojantys Jungtinių Valstijų istatymai.

2. Politinio veiksmo komitetų (PACs ir Super PACs), kurių paskirtis rinkti lěšas, veikla.

3. Politinių lèšų rinkimas iš individualių aukotojų.

Šioje straipsnio dalyje analizuojama mokslinẻ literatūra skirstoma pagal tokias tris temas.

Politinị finansavimą ir lèšų rinkimą reguliuojantys Jungtinių Valstijų îstatymai. Politinio finansavimo tyrimų problematikai didelę itaką turèjo naujų įstatymų prièmimas. 1972 metais prezidentas Richardas Nixonas pasirašè Federalinị rinkimų kampanijos aktą ${ }^{32}$, vèliau jis buvo keičiamas 1974, 1976 ir 1979 metais. Aktas ir jo pakeitimai nustatè aiškius lèšu rinkimo ir išlaidų per rinkimus limitus (vèliau jie buvo pripažinti prieštaraujantys Konstitucijai), numatẻ būtinybę registruoti visas aukas ir stambiuosius rèmejus, taip pat ir Federalinès rinkimų komisijos, prižiūrinčios Jungtinių Valstijų rinkimų kampanijų lèšas, ịkūrimą. Svarbiausias šio teisès akto tikslas - sumažinti turtingų rèmèjų ịtaką šalies politikai.

Federalinio rinkimų kampanijos akto prièmimas turèjo didelę ịtaką šalies politinio finansavimo tvarkai, tad mokslininkai èmé analizuoti jo padarinius ir dažnai jų požiūriai skyrèsi. Samuelis Issacharoffas ir Pamela S. Karlan kritikavo ši aktą ir teigè, kad praejjus ketvirčiui amžiaus nuo jo prièmimo šalies politika pasirodè „kaip niekada beprasmè, varoma pinigų, uždara"33. F. Leslie Seidle’as taip pat pažymèjo, kad šis aktas neturejjo teigiamo efekto kontroliuojant kampanijų kaštus, tačiau, anot jo, bent jau padarè rinkimus skaidresnius dèl ịvesto griežtesnio pinigų srautų ir rèmèjų registracijos reikalavimo ${ }^{34}$. Micha-

32 Angl. Federal Election Campaign Act (FECA).

${ }^{33}$ Karlan, Pamela S.; Issacharoff, Samuel. The Hydraulics of Campaign Finance Reform. Texas Law Review. 1999, vol. 77, no. 7.

${ }^{34}$ Seidle, F. Leslie. Comparative Issues in Party and Election Finance. Dundurn Press, 1991. 268 p. 
elas Patrickas Allenas ir Philipas Broylesas tyrinèjo turtingų Jungtinių Valstijų šeimų aukojimo statistiką nuo 1972 iki 1984 metų ir nustatė, kad igyvendinus Federalinị rinkimų kampanijos aktą sumažèjo kandidatams aukojančių milijonierių ir milijardierių skaičius ir jų aukojamų sumų dydis, tačiau nesumenko galutinès kandidatų surenkamų aukų sumos $^{35}$. Tai rodo, kad akto igyvendinimas padejo sumažinti turtingų šeimų ịtaką politikams, bet neatèmè iš politikų galimybès surinkti didžiulị kiekị lèšų, kaip ir anksčiau, - tik iš gausesnio skaičiaus ịvairių aukotojų.

2002 metais buvo priimtas Dvipartinès kampanijos reformos ak$\operatorname{tas}^{36}$, vienas iš naujausių ịstatymų, turinčių didelę ịtaką finansams. Juo irgi siekta apriboti turtingų rèmèjų įtaką, taip pat ir bandymą ịvesti papildomus lèšų rinkimo ir išlaidų limitus, kurių dalị Aukščiausiasis Teismas ir vèl panaikino. Akto prièmimas sulaukė nemenko tyrëjų dèmesio. Kampanijų lèšas tyrinejjantys mokslininkai Michaelas J. Malbinas, Anthony Corrado ir Raymondas La Raja „Politikos analizės ir vadybos žurnale“ („Journal of Policy Analysis and Management“) diskutavo, ar Dvipartinès kampanijos reformos aktas stiprina Jungtinių Valstijų politinę sistemą, ir pateikè du priešingus požiūrius. A. Corrado nuomone, aktas yra naudingas, nes padeda išvengti korupcijos politikoje ir padidina finansinių transakcijų skaidrumą, o R. La Raja teigè, kad aktas neadekvačiai silpnina šalies partijas, suteikdamas didelę galią nuo partijų nepriklausančioms politikos dalyvių grupèms, o tai menkina visą politinę sistemą ${ }^{37}$. Atskirame straipsnyje R. La Raja taip pat aiškino, kad aktas išlaiko ankstesnès sistemos trūkumus, atsikratęs jos

${ }^{35}$ Allen, Michael Patrick; Broyles, Philip. Campaign Finance Reforms and the Presidential Campaign Contributions of Wealthy Capitalist Families. Social Science Quarterly (University of Texas Press). 1991, vol. 72, no. 4, p. 738-750.

${ }^{36}$ Angl. Bipartisan Campaign Reform Act (BCRA).

${ }^{37}$ Malbin, Michael J.; Corrado, Anthony; La Raja, Raymond. Will the BCRA strengthen the political system? Journal of Policy Analysis and Management. 2005, vol. 24, no. 3, p. 599-610. 
pranašumų ${ }^{38}$. Davidas B. Magleby, Bradley Jonesas ir Davidas Lassenas tyrẻ, kokią ịtaką šio ịstatymo, dažnai laikyto neparankiu Demokratų partijai, prièmimas turèjo demokratų politikų galimybèms rinkti lèšas, ir nustatè, kad demokratai sẻkmingai varžèsi rinkdami lèšas ir, nors prognozuota priešingai, nenusileido respublikonams ${ }^{39}$.

Politinio finansavimo tyrimams aktualus ir 2010 metais paskelbtas Aukščiausiojo Teismo sprendimas organizacijos „Citizens United“ ir šalies rinkimų komisijos byloje. Šiuo sprendimu nepolitinès organizacijos igavo teisę neribotai rinkti ir leisti lěšas politiniais tikslais. Tai lèmè svarbius pokyčius Jungtinių Valstijų politinio finansavimo diskurse, nes buvo steigiami nepriklausomų išlaidų politinio veiksmo komitetai, kurie greitai virto labai svarbiu kandidatų i prezidentus finansavimo įrankiu. Plačiau moksliniai politinio veiksmo komitetų ir nepriklausomų išlaidų politinio veiksmo komitetų tyrimai analizuojami kitame skirsnyje.

Politinio veiksmo komitetų (PACs ir Super PACs), kurių paskirtis rinkti lèšas, veikla. Federalinio rinkimų kampanijos akto prièmimas 1972 metais apribojo ir politinio veiksmo komitetų veiklą. Naujos sąlygos paskatino politinio veiksmo komitetų atsiradimo tyrimus, o jų rezultatai ne visada buvo vienodi. Pavyzdžiui, Andrew P. Buchsbaumas analizavo politinio veiksmo komitetų, renkančių lèšas kandidatams, išpopuliarejjimą tuo metu, kai Aukščiausiasis Teismas panaikino Federaliniame rinkimų kampanijos akte numatytus išlaidų limitus. A. P. Buchsbaumas nustatė, kad iš to kyla tokių problemų kaip atsirandanti kandidatų priklausomybè nuo komitetų arba komitetų atskaitomybès trūkumas ${ }^{40}$. Johnas R. Mulkernas, Edwardas Handleris

${ }^{38}$ La Raja, Raymond. From Bad to Worse: The Unraveling of the Campaign Finance System. The Forum. 2008, vol. 6, no. 1.

${ }^{39}$ Magleby, David B.; Jones, Bradley; Lassen, David. Turning the Tables: Individual Contributions, Member Contributions, and the Changing Campaign Finance Environment. The Forum. 2009, vol. 7, no. 1.

${ }^{40}$ Buchsbaum, Andrew P. Campaign Finance Re-Reform: The Regulation of Independent Political Committees. California Law Review. 1983, vol. 71, no. 2. 
ir Lawrence'as Godtfredsenas tyrè tuometinę korporatyvinių politinio veiksmo komitetų finansinę galią ir įvertino ją tik kaip „kuklią“41.

XXI amžiuje tyrimai ir mokslinès diskusijos apie politinio veiksmo komitetų îtaką politikai tęsèsi. Jeffrey Milyo, Davidas Primo ir Timothy Groseclose’as teigè, kad šių komitetų veiklai skiriama per daug dèmesio, nes ịplaukos iš jų sudaro vos 10 proc. kampanijų išlaidų Kongreso rinkimuose ${ }^{42}$. Claytonas D. Peoplesas išnagrinèjo daugeli politinio veiksmo komitetų įtaką analizuojančių mokslinių straipsnių ir nustatè, kad jų reikšmę Kongrese retai galima prilyginti grynu „paslaugos už paslaugą" apsikeitimu, tačiau dažniausiai ị politiką investuojančios interesų grupès sulaukia dividendų, net jei jie ir nebūna iš anksto pažadèti ${ }^{43}$.

Politinio veiksmo komitetus aprašantys moksliniai straipsniai XXI amžiuje turi savitų bruožų, mažiau būdingų ankstesniems tyrimams. Pastaraisiais metais daugiau mokslininkų tyrinejjo politinio veiksmo komitetų veiklą iš lyčių lygybès perspektyvos. Pavyzdžiui, Peteris Francia tyrè moterų politinio veiksmo komitetų itaką ir nustatė, kad moterų komitetai kampanijos pradžioje aukoja išskirtinai daug lèšų Demokratų partijos kandidatèms. Taip jie padeda vẻliau surinkti joms lèšų ir iš kitų rẻmèjų ir sulaukti didesnio rinkèjų palaikymo ${ }^{44}$. Christine Day ir Charlesas Hadley analizavo dviejų moterų politinio veiksmo komitetų, prijaučiančių skirtingoms politinèms jègoms - respublikonams bei demokratams, aukojimo ypatumus ir nustatė, kad abu komitetai aukojo moterims kandidatèms, pasisakančioms už abortų

${ }^{41}$ Mulkern, John R.; Handler, Edward; Godtfredsen, Lawrence. Corporate PACs as Fundraisers. California Management Review. 1981, vol. 23, no. 3, p. 49-55.

${ }^{42}$ Milyo, Jeffrey; Primo, David; Groseclose, Timothy. Corporate PAC Campaign Contributions in Perspective. Business \& Politics. 2000, vol. 2, no. 1.

${ }^{43}$ Peoples, Clayton D. Campaign Finance and Policymaking: PACs, Campaign Contributions, and Interest Group Influence in Congress. Sociology Compass. 2013, vol. 7 , no. 11.

${ }^{44}$ Francia, Peter. Early Fundraising by Nonincumbent Female Congressional Candidates: The Importance of Women's PACs. Women \& Politics. 2001, vol. 23, no. $1 / 2$. 
legalizavimą, nors šių moterų pažiūros kitais klausimais buvo visiškai skirtingos ${ }^{45}$.

Dar plačiau analizuojama viena iš politinio veiksmo komitetų rūšių - nepriklausomų išlaidų politinio veiksmo komitetai ${ }^{46}$. Šie komitetai igavo galią 2010 metais, Aukščiausiajam Teismui prièmus sprendimą organizacijos „Citizens United“ ir šalies rinkimų komisijos byloje. Nepriklausomų išlaidų politinio veiksmo komitetai pasižymi tuo, kad negali tiesiogiai remti kandidatų finansiškai, tačiau turi teisę už neribotą sumą pirkti už kandidatus ar prieš juos nukreiptą reklamą žiniasklaidoje. Šių komitetų išpopuliarejjimas ir vis didejjanti jų ịtaka lèmé, kad daugelis mokslininkų susidomėjo nepriklausomų išlaidų politinio veiksmo komitetų ypatumais. Pavyzdžiui, Richardas Briffaultas išsamiai išanalizavo nepriklausomų išlaidų politinio veiksmo komitetus ir teigè, kad šių grupių atsiradimą galima laikyti nauja Jungtinių Valstijų politikos era ${ }^{47}$. Girishas Gulati tyrè šių komitetų veiklą prieš 2012 metų prezidento rinkimus ir pasidalijo įžvalgomis, kokią ịtaką jie gali turèti ateities rinkimams. Anot jo, nepriklausomų išlaidų politinio veiksmo komitetai yra ir bus itin reikšmingi politinių kampanijų dalyviai, kurių bene vienintelè silpnoji vieta - būtinybè skelbti komitetui aukojusių asmenų vardus ir pavardes ${ }^{48}$. Šia tema tyrimus atliko ir Melissa M. Smith bei Larry Powellas. Jie ne tik analizavo nepriklausomų išlaidų politinio veiksmo komitetų veiklą, bet ir siūlè padarius pataisą Konstitucijoje uždrausti šios rūšies komitetams dalyvauti politikoje $\mathrm{e}^{49}$.

45 Day, Christine L.; Hadley, Charles D. Who Contributes? Similarities and Differences Between Contributors to EMILY'S List and WISH List. Women \& Politics. 2002, vol. 24, no. 2.

46 Angl. Super PACs.

47 Briffault, Richard. Super PACs. Minnesota Law Review. 2012, vol. 96, no. 5.

${ }^{48}$ Gulati, Girish. Super PACs and Financing the 2012 Presidential Election. Society. 2012, vol. 49, no. 5.

49 Smith, Melissa M.; Powell, Larry. Dark Money, Super PACs, and the 2012 Election. Lexington Books, 2014. 126 p. 
Politinių lèšų rinkimas iš individualių aukotojų. XX a. antroje pusejje politinio finansavimo tyrimų lauke imta nuodugniau analizuoti lěšų rinkimo tiesiogiai iš individualių aukotojų galimybes, įskaitant ir nedideles aukas iš "paprastų žmonių “50. Ruth S. Jones ir Anne H. Hopkins išnagrinėjo lěšų rinkimo iš individualių aukotojų būdus ir išskyrė keturis pagrindinius. Tai būtų: tiesiogiai paštu siunčiami popieriniai laiškai, telefoniniai skambučiai, tiesioginis (akis $\mathfrak{i}$ akị) asmeninis kreipimasis ir grupinis kreipimasis ${ }^{51}$. Cliffordas W. Brownas (jaun.), Lynda W. Powell ir Clyde’as Wilcoxas analizavo lěšų rinkimo būdus, taikytus 1988 ir 1992 metų prezidento nominacijos rinkimuose - nuo paremti kviečiančių popierinių laiškų iki asmeninio kreipimosi, taip pat tyrè kandidatų turimų išteklių poveikị lèšų rinkimo būdams, gvildeno pagrindinius aukojimo motyvus: tikslą, solidarumą ir materialinị suinteresuotumą ${ }^{52}$.

Politini finansavimą tiriantys autoriai XXI amžiuje ėmė dar dažniau rašyti tokius mokslo darbus, kuriuose iš visų politinio finansavimo temų tyrinėjamas tik lèšų rinkimas iš atskirų asmenų. Tai lėmė ir jau minèti naujai priimti įstatymai, ir atsiradusios galimybès rinkti lèšas internetu. Kai kurie autoriai tyrè geografinių veiksnių itaką politikų ir partijų vykdomam lèšų rinkimui. Pavyzdžiui, Jamesas G. Gimpelas, Francesas E. Lee ir Joshua Kaminski nustatè, kad geografinè vietovè, kurioje žmogus gyvena, turi ịtakos jo sprendimui aukoti lěšų politikams, ir ta ịtaka yra nepriklausoma nuo tokių asmens demografinių ypatumų kaip finansinè padètis, amžius ar profesija ${ }^{53}$.

50 Angl. ,grassroots " fundraising.

51 Jones, Ruth S.; Hopkins, Anne H. State Campaign Fund Raising: Targets and Response. The Journal of Politics. 1985, vol. 47, no. 2.

52 Brown, JR., Clifford, W.; Powell, Lynda W.; Wilcox, Clyde. Serious money: fundraising and contributing in presidential nomination campaigns. Cambridge University Press, 1995. 197 p.

${ }^{53}$ Gimpel, James G.; Lee, Frances E.; Kaminski, Joshua. The Political Geography of Campaign Contributions in American Politics. The Journal of Politics. 2006, vol. 68 , no. 3 . 
P. Francia su kolegomis išsamiai tyrè stambiųjų individualių rèmèjų, aukojančių daugiau nei po 200 dolerių, įtaką Kongreso rinkimams, be to, siekè nustatyti, kokie žmonès rinkimams aukoja dideles sumas, kiek kandidatų ir kokiomis sumomis jie remia, kas juos motyvuoja ${ }^{54}$. Smulkiomis aukomis politikus remiančių aukotojų vaidmeni tyrę Wesley Y. Joe et al. nustaté, kad smulkieji rèméjai skiriasi nuo stambiųjų rẻmėjų, o savo pažiūromis kai kuriais atvejais yra panašesni i visai neaukojančius asmenis nei ị stambiuosius rèméjus. Smulkieji rèmėjai tyrime išsiskyrè tuo, kad jie dažniau aukojo nesitikèdami patenkinti savo pačių ekonominių interesų, taip pat, be finansinès paramos, jie dažniau kampanijai skyre ir savo laiko, t. y. tapo kampanijos savanoriais ${ }^{55}$.

Individualių rèmèjų tema tyrinèta ir kitais aspektais. Štai Russellas N. Jamesas III aiškinosi politikams aukojančių namų ūkių socialinius bei ekonominius ypatumus ir nustatè, kad politikus dagiausia remia dideles pajamas gaunančių, išsilavinusių baltaodžių namų ūkiai ${ }^{56}$. Jamesas J. Feigenbaumas ir Cameronas A. Sheltonas nustate, kad žmonès per pirminius rinkimus ${ }^{57}$ daug labiau linkę aukoti pinigų tiems kandidatams, kurie laikomi turinčiais daugiau šansų laimèti ${ }^{58}$. Per 2008 ir 2012 metų prezidento rinkimus itin ryškiai išaugo smulkiụjų rèmejjų skaičiaus, tad politinę situaciją ịvairiuose mokslo darbuose išsamiai išanalizavo ir Michaelas J. Malbinas, tiriantis ịvairius šios temos

${ }^{54}$ Francia, Peter L.; Green, John C.; Herrnson, Paul S.; Powell, Lynda W.; Wilcox, Clyde. The Financiers of Congressional Elections: Investors, Ideologues, and Intimates. Columbia University Press, 2003. 216 p.

55 Joe, Wesley Y.; Malbin, Michael J.; Wilcox, Clyde, Brusoe, Peter W.; Pimlott, Jamie P. Do Small Donors Improve Representation? Some Answers from Recent Gubernatorial and State Legislative Elections. The CFI Small Donor Project, 2008.

56 James III, Russell N. An econometric analysis of household political giving in the USA. Applied Economics Letters. 2009, vol. 16, no. 5.

57 Angl. primaries.

${ }^{58}$ Feigenbaum, James J.; Shelton, Cameron A. The Vicious Cycle: Fundraising and Perceived Viability in US Presidential Primaries. Quarterly Journal of Political Science. 2013, vol. 8, no. 1. 
aspektus. M. J. Malbinas pabrěžè, kad, net ir matant sėkmingą Baracko Obamos pavyzdị savarankiškai renkant lèšas, kandidatams turi būti išlaikyta galimybè gauti lèšu ir iš valstybès ${ }^{59}$.

Analizuojant lèšu rinkimo iš individualių asmenų tendencijas XXI amžiuje, dèmesys skiriamas interneto, kaip lèšų rinkimo kanalo, tyrimui. Tokie tyrimai paprastai apima ne vien lèšų rinkimo internetu analizę. Dažniausiai tam tikri rinkimai tyrinejjami plačiai, pavyzdžiui, analizuojamas politinis finansavimas per konkrečius rinkimus, taip pat atsižvelgiant ir ị lěšų rinkimo internetu tendencijas, arba tiriama vien interneto įtaka konkretiems rinkimams, atsižvelgiant ir i galimybes internetu rinkti lèšas. Josephas Grafas, išanalizavęs interneto įtaką renkant lèšas 2004 metų prezidento rinkimų laikotarpiu, ypač kandidato Howardo Deano kampanijoje, prognozavo dar didesnę šio komunikacijos kanalo reikšmę rinkimams ateityje ${ }^{60}$. Panašaus požiūrio laikèsi ir Matthew Hindmanas, kuris nagrinejo, kaip internetas buvo naudojamas H. Deano komunikacijos kampanijoje. Jis pabrèžè, kad šiuo atveju H. Deano vykdyto lěšų rinkimo reikšmė buvo milžiniška ${ }^{61}$. Tačiau, Costo Panagopoulos ir Danielio Bergano teigimu, nepaisant žiniasklaidos dėmesio interneto reikšmei, iš tiesų aukotojų skaičius padidejo dẻl išaugusio susidomejjimo rinkimais, o ne technologijų itakos ${ }^{62}$. Be to, C. Panagopoulos ir D. Berganas tyrè aukotojų internetu ir tradiciniais kanalais ypatybes ${ }^{63}$.

${ }_{59}$ Malbin, Michael J. Small Donors, Large Donors and the Internet: The Case for Public Financing after Obama. The Campaign Finance Institute, 2009. Prieiga per internetą: http://www.cfinst.org/president/pdf/PresidentialWorkingPaper_April09. pdf [žiūrèta $2016 \mathrm{~m}$. lapkričio $20 \mathrm{~d}$.].

${ }^{60}$ Graf, Joseph. Donors and Fundraising in the 2004 Presidential Campaigns. National Civic Review. 2006, vol. 95, no. 3.

${ }^{61}$ Hindman, Matthew. The Real Lessons of Howard Dean: Reflections on the First Digital Campaign. Perspectives on Politics. 2005, vol. 3, no. 1.

62 Panagopoulos, Costas; Bergan, Daniel. Contributions and Contributors in the 2004 Presidential Election Cycle. Presidential Studies Quarterly. 2006, vol 36, no. 2.

63 Panagopoulos, Costas; Bergan, Daniel. Online Fund-Raising and Contributors in the 2004 Presidential Campaign. Social Science Computer Review. 2007, vol. 25, no. 4. 
Ypač plačiai tyrinèta 2008 metų Jungtinių Valstijų prezidento rinkimų kampanija ir jos metu Baracko Obamos plètota lèšų rinkimo komunikacija. Išsamiai 2008 metų prezidento ir Kongreso rinkimų lèšas išanalizavo Davidas B. Magleby ir Anthony Corrado su komanda. Kaip ir daugelis kitų autorių, jie teige, kad šie istoriniai rinkimai ir nauji lèšų rinkimo būdai gali visam laikui pakeisti Jungtinių Valstijų politiką ${ }^{64}$.

Mokslo darbuose dažnai tiriami interneto komunikacijos ypatumai 2008 metų rinkimuose, išskiriant lěšų rinkimą internete kaip vieną iš tyrimų objektų, bet ne vieninteli. Pavyzdžiui, Johnas Allenas Hendricksas ir Robertas E. Dentonas (jaun.) analizavo, kaip naujųjų technologijų naudojimas padejo B. Obamai laimèti. Anot jų, esminis lèšu rinkimo įrankis B. Obamos kampanijoje buvo elektroninis paštas $^{65}$. Derrickas L. Cogburnas ir Fatima K. Espinoza-Vasquez tyrè interneto įtaką pilietiniam aktyvumui šiuose rinkimuose. Kaip vieną iš trijų tyrimo aspektų jie nurodè socialinị-techninị faktorių, lèmusị B. Obamos sèkmę renkant lěšas internetu. Kaip reikšmingiausią veiksnị jie taip pat nurodè nuolatinị personalizuotų elektroninių laiškų, kuriuose buvo prašoma finansinès paramos, siuntimą ${ }^{66}$. Mitchellas S. McKinney ir Mary C. Banwart su kolegomis irgi analizavo per 2008 metų rinkimus internete plètotą komunikaciją, be to, ir internetu renkamas lèšas. Autorių nuomone, pagrindinė B. Obamos sèkmès renkant lèšas priežastis - ypač stipri interneto komunikacijos profesionalų komanda, išaugusi iki 30 darbuotojų, tarp kurių buvo ir tokių savo

${ }^{64}$ Financing the 2008 Election: Assessing Reform (red. MAGLEBY, David B.; CORRADO, Anthony). Brookings Institution Press, 2011. 341 p.

${ }^{65}$ Communicator-in-Chief: How Barack Obama Used New Media Technology to Win the White House (red. Allen Hendricks, John; Denton JR., Robert E.). Lexington Books, 2010. $188 \mathrm{p}$.

${ }^{66}$ Cogburn, Derrick L.; Espinoza-Vasquez, Fatima K. From Networked Nominee to Networked Nation: Examining the Impact of Web 2.0 and Social Media on Political Participation and Civic Engagement in the 2008 Obama Campaign. Journal of Political Marketing. 2011, vol. 10, no. 1-2. 
srities specialistų kaip buvę H. Deano komandos nariai bei vienas iš „Facebook“ ịkūrèjų ${ }^{67}$.

Praejus ketveriems metams, 2012-ais B. Obama pakartojo ankstesnių rinkimų, vykusių 2008 metais, sèkmę renkant lèšas ir net pagerino rezultatus. Davidas B. Magleby su kolegomis atskiruose leidiniuose aprašè kiekvienų Jungtinių Valstijų prezidento rinkimų nuo 2000 metų finansavimą. Jie plačiai ištyrè ir 2012 metų prezidento rinkimų finansavimą: kokie buvo surinktų lèšų šaltiniai, kaip lèšos buvo naudojamos, kokių rezultatų sulaukta veikiant skirtingais būdais ir kokia buvo interesų grupių ittaka šiems rinkimams. Pastebèta, kad B. Obama ne tik surinko daugiau lèšų už oponentą Mittą Romney, bet ir turèjo didesnių galimybių kontroliuoti surinktus pinigus, o M. Romney dažnai turèjo pasikliauti nepriklausomų išlaidų politinio veiksmo komitetais ${ }^{68}$.

Interneto priemonių naudojimas 2012 metų rinkimuose taip pat buvo tyrinètas, nors šiuose rinkimuose, nepaisant surinktos rekordinès lèšų sumos, interneto priemonių naudojimas nesukèle tokio perversmo kaip 2008 metų interneto kampanija. Jenny Bronstein tyré, kaip kandidatai ị Jungtinių Valstijų prezidentus per 2012 metų kampanijas lèšoms rinkti ir savanoriams organizuoti išnaudojo socialines medijas. Ji pristatè terminą „aistruolių politika"69, kuris apibūdina socialinèse medijose kandidatų santykį su rinkejjais, paremtą ne protu ir logika, o emociniu jautrumu ${ }^{70}$. Jennifer Stromer-Galley atliko išsamią penkerių prezidento rinkimų nuo 1996 iki 2012 metų analizę ir išaiškino, kaip kiekvienuose iš šių rinkimų buvo išnaudojamos interneto galimybės komunikacijai plètoti ir lèšoms rinkti. J. Stromer-Galley teigimu, B. Obamos sẻkmę renkant lèšas lèmé ne tik interneto inovacijų

${ }^{67}$ Communication in the 2008 U.S. Election: Digital Natives Elect a President (red. Mckinney, Mitchell S.; Banwart, C.). Peter Lang Publishing Inc, 2010. 329 p.

${ }^{68}$ Magleby, David B. Financing the 2012 Election. Brookings Institution Press, 2014. 240 p.

${ }^{69}$ Angl. fandom politics.

${ }^{70}$ Bronstein, Jenny. Like me! Analyzing the 2012 presidential candidates' Facebook pages. Online Information Review. 2013, vol. 37, no. 2. 
išnaudojimas, bet ir daugiau įvairių veiksnių: 1) jo kandidatavimas pritraukė maištautojų ir jaunimo auditorijas, kurioms interneto erdvė yra geriausiai pažistama ir artima; 2) jo kampanijos žinutè, kad kiekvienas iš mūsų gali daryti pokyčius, buvo tinkamai suderinta su interneto strategija (B. Obamos interneto platformose žmonès iš tiesų galejo prisidèti prie pokyčių); 3) jo surinkta patyrusių profesionalų komanda geriau nei bet kas kitas suvoké, kaip plètoti komunikaciją ir kada ${ }^{71}$.

Apibendrinant galima teigti, kad pastaruosius kelerius metus politinio finansavimo situacija Jungtinèse Valstijose yra smarkiai besikeičianti. $\mathrm{XX}$ a. antroje pusèje beveik visi kandidatai i prezidentus pirminiuose rinkimuose prièmė valstybès skiriamas lèšas, taip atsisakydami galimybès patys neribotai rinkti lěšas. Iki 2008 metų visi kandidatai priėmė valstybès lèšas per visuotinius prezidento rinkimus. B. Obama 2008 metais pirmasis visiškai atsisakè valstybès paramos tiek per pirminius, tiek per visuotinius rinkimus ir surinko tuo metu rekordinę lèšu sumą - beveik 750 milijonų $^{72}$. Nuo 2012 metų rinkimų visi kandidatai atsisako valstybès finansavimo ir, savarankiškai rinkdami lěšas, toliau gerina rekordus ${ }^{73}$.

Šiuos pokyčius lemia ne tik besikeičiantys ịstatymai, bet ir naujos lèšų rinkimo galimybės, kurias teikia internetas. 2004 metų prezidento rinkimai ir ypač H. Deano kampanija per pirminius rinkimus tik parodè interneto galimybes renkant lèšas, o po 2008, 2012 ir 2016 metų prezidento rinkimų paaiškejjo, kad interneto komunikacijos galimybès mobilizuojant piliečius ir renkant lèšas gali turèti esminę ịtaką rinkimų baigčiai. Todèl nenuostabu, kad interneto komunikacija ir jos galimybės renkant lèšas tampa svarbiu Jungtinių Valstijų mokslininkų tyrimų

71 Stromer-Galley, Jennifer. Presidential Campaigning in the Internet Age. Oxford University Press, 2014. 240 p.

${ }^{72}$ Luo, Michael. Obama Hauls in Record \$750 Million for Campaign. The New York Times, 2008. Prieiga per internetą: http://www.nytimes.com/2008/12/05/us/ politics/05donate.html [žiūrèta $2016 \mathrm{~m}$. gruodžio $15 \mathrm{~d}$.].

73 Thompson, Marilyn W. The Price of Public Money. The Atlantic, 2016. Prieiga per internetą: http://www.theatlantic.com/politics/archive/2016/05/the-price-of-publicmoney/484223/ [žiūrèta 2016 m. gruodžio 15 d.]. 
objektu. Kokia situacija politinio finansavimo srityje vyrauja Europos šalyse ir kaip keitèsi mokslininkų tyrimai šia tema, analizuojama kitoje straipsnio dalyje.

\section{Politinio finansavimo tyrimai Europoje: valstybès finansavimas, įstatymai ir lèšų įtaka rinkimų rezultatams}

XX amžiuje mokslininkų, rašančių apie politinị finansavimą, aktyvumas ir ịdirbis Jungtinėse Valstijose buvo daug didesnis nei kitose pasaulio valstybėse. Net pirmoji Europos valstybių politinio finansavimo analizė buvo atlikta ne pačioje Europoje, bet Jungtinèse Valstijose, kai Jamesas K. Pollockas 1932 metais ištyrė politinį finansavimą Jungtinejje Karalystèje, Airijoje, Vokietijoje ir Prancūzijoje. J. K. Pollockas aprašè ìvairius šių šalių politinio finansavimo aspektus: lèšų rinkimo šaltinius, lèšų panaudojimo būdus, išlaidų dydị, lèšų ịtaką šalių politikai ir politinị finansavimą reguliuojančius ịstatymus ${ }^{74}$. Tik antroje amžiaus pusejje už Jungtinių Valstijų ribų ėmè rastis daugiau šias temas nagrinėjančių publikacijų, kuriose lyginamos kelios šalys arba analizuojami konkrečių šalių, daugiausia Europos, atvejai.

Pirmieji politinio finansavimo tyrimai XX a. antroje pusejje buvo atliekami atskirose šalyse. Pavyzdžiui, Arnoldas J. Heidenheimeris išanalizavo Vokietijos krikščionių demokratų sąjungos finansavimą ir nustatè, kad pati partija galètų išlaikyti tik penktadalị savo organizacinio pajègumo, todèl jai yra būtina išorinè parama ${ }^{75}$. Tuo laikotarpiu Vokietijoje partijos nebuvo remiamos valstybès, taip pat trūko politinị finansavimą ribojančių istatymų, tad priklausomybè nuo individualių ir verslo rèmèjų buvo akivaizdi. Dèl šios priežasties 1958 metais šalies Konstitucinis Teismas pritarè, kad politinès partijos būtų remiamos

${ }^{74}$ Pollock, James K. Money and Politics Abroad. A. A. Knopf, New York, 1932. 328 p. ${ }^{75}$ Heidenheimer, Arnold J. German Party Finance: The CDU. The American Political Science Review. 1957, vol. 51, no. 2. 
valstybės, o 1967 metais Vokietijoje buvo išleistas ir tai išsamiai apibrěžiantis įstatymas, aktualus iki šiol. Vokietija tapo pirmąja Europos valstybe, ịteisinusia tiesiogini partijų finansavimą valstybès lèšomis.

Justinas Fisheris išsamiai išanalizavo Jungtinès Karalystès konservatorių partijos finansavimą. Anot jo, ši partija, remiama individualių ir verslo rèmejų, sulaukia pagrịsto visuomenès pasipiktinimo ir įtarimų, kad neatskleidžia dalies aukotojų tapatybès. J. Fisherio nuomone, tokia situacija verčia galvoti apie politinio finansavimo įstatymų keitimą ir griežtesnị reguliavimą. Kaip viena iš alternatyvų, J. Fisherio teigimu, galètų būti valstybès finansavimas, skiriamas partijoms. Tačiau jis priduria, kad toks pakeitimas būtų "ne mažiau kontroversiškas " ${ }^{\text {"76 }}$. J. Fisherio minimos problemos buvo išspręstos - 2000 metais šalyje priimtas Politinių partijų rinkimų ir referendumų aktas ${ }^{77}$ sugriežtino privalomą visų aukotojų registraciją ir numatė griežtus limitus, kiek lèšų partijos gali išleisti prieš rinkimus.

Be atskirų valstybių ir jų partijų finansavimo analizès, XX a. antroje pusėje mokslininkai èmė daryti plačius tyrimus, apimančius bent keletą šalių. Pavyzdžiui, Arthuras Gunlicksas tyrė politinị finansavimą Šiaurès Amerikoje ir Vakarų Europoje ${ }^{78}$, o F. L. Seidle’as analizavo ir lygino politini finansavimą Jungtinèse Valstijose, Kanadoje, taip pat Vokietijoje ir kitose Vakarų Europos valstybėse ${ }^{79}$. Herberto E. Alexanderio surinkta mokslininkų komanda išsamiai ištyrė ir palygino politinį finansavimą vienuolikoje šalių ịvairiuose žemynuose ${ }^{80}$. Pasauliniu mastu politinis finansavimas gvildentas ir XXI amžiuje - ji globaliai

${ }^{76}$ Fisher, Justin. Political Donations to the Conservative Party. Parliamentary affairs. 1994, vol. 47, no. 1.

77 Angl. Political Parties Elections and Referendums Act.

${ }^{78}$ Gunlicks, Arthur. Campaign and Party Finance in North America and Western Europe. Westview Press, 1993. 278 p.

79 Comparative Issues in Party and Election Finance. (red. Seidle, F. Leslie). Dundurn Press, 1991. 268 p.

${ }^{80}$ Comparative Political Finance in the 1980s. (red. Alexander, Herbert E.). Cambridge University Press, 1989. 288 p. 
tyrinejjo Karlas-Heinzas Nassmacheris ${ }^{81}$ ir kiti mokslininkai. Šių ir kitų mokslo darbų analizè leidžia teigti, kad Europos šalyse politinio finansavimo tyrimuose vyrauja trys kryptys:

1. Partijų finansavimo valstybès lèšomis ypatumai.

2. Politinị finansavimą ir lěšu rinkimą reguliuojantys įstatymai.

3. Lèšų ịtaka rinkimų rezultatams.

Šioje straipsnio dalyje analizuojama mokslinè literatūra yra skirstoma pagal tokias tris temas.

Partijų finansavimo valstybès lèšomis ypatumai. Partijų finansavimo valstybės lěšomis įtaka politikai plačiai tyrinèta Europoje, kur pastaruosius keletą dešimtmečių vis daugiau valstybių prièmé ịstatymus, nustatančius valstybės dotacijas partijoms. Jonas Pierre'as, Larsas Svåsandas ir Andersas Widfeldtas analizavo partijų finansavimo valstybès lèšomis įvedimą ịvairiose išsivysčiusiose šalyse ir nustatẻ, kad toks pasikeitimas neturèjo didelès ịtakos valstybès politinei sistemai, taip pat nesumenkino ir kitų finansavimo šaltinių reikšmès partijoms ${ }^{82}$. Susan E. Scarrow tyrè partijų finansavimo valstybės lèšomis ịtaką partijų konkurencingumui Europos Sąungos šalyse ir nerado įrodymų, kad valstybès dotacijos darytų teigiamą ar neigiamą ịtaką partijų konkurencijai ${ }^{83}$. Ingrid van Biezen ir Petras Kopecký analizavo Pietų ir Rytų Europos šalių atvejus ir atskleidè, kad valstybės dotacijos tapo išskirtinai svarbia partijų finansavimo dalimi. Anot autorių, tai padeda palaikyti politinès sistemos stabilumą, kuriam sąlyginai naujose Pietų ir Rytų Europos valstybėse kitu atveju kiltų pavojus ${ }^{84}$.

${ }^{81}$ Nassmacher, Karl-Heinz. The Funding of Party Competition: Political Finance in 25 Democracies. Nomos Publishers, 2009. 467 p.

${ }^{82}$ Pierre, Jon; Svåsand, Lars; Widfeldt, Anders. State subsidies to political parties: Confronting rhetoric with reality. West European Politics. 2000, vol. 23, no. 3.

${ }^{83}$ Scarrow, Susan E. Party subsidies and the freezing of party competition: Do cartel mechanisms work? West European Politics. 2006, vol. 29, no. 4.

${ }^{84}$ Van Biezen, Ingrid; Kopecký, Petr. On the predominance of state money: Reassessing party financing in the new democracies of Southern and Eastern Europe. Perspectives on European Politics and Society. 2001, vol. 2, no. 3. 
Politinị finansavimą ir lèšų rinkimą reguliuojantys ịstatymai. Politines lèšas reguliuojantys ịstatymai daugelyje valstybių tapo plačiai tiriamu objektu. Benas Cliftas ir J. Fisheris tyrė Jungtinès Karalystės ir Prancūzijos politinị finansavimą reguliuojančių ịstatymų panašumus bei skirtumus. Jie pastebèjo, kad Prancūzijos politinès partijos dèl ịsigalejusių įstatymų tapo priklausomos nuo valstybės, o Jungtinès Karalystès politinès partijos turi daugiau galimybių išvengti valstybės kišimosi i politinio finansavimo sferą ${ }^{85}$. Riccardo Pelizzo tyrè Italijos ir Vokietijos politinio finansavimo įstatymus ir analogiškai įvertino, kad Vokietijos politinėms partijoms pavyko išlaikyti nepriklausomybę nuo valstybės, o Italijos partijos tapo priklausomos nuo valstybės dotacijų ${ }^{86}$.

Michaelas Pinto-Duschinsky analizavo politinio finansavimo ịstatymus įvairiose pasaulio šalyse. Jis atkreipè demesị i globalią problemą - daugelyje valstybių, tarp jų ir išsivysčiusiose, galiojantys politinio finansavimo ịstatymai nereiškia, kad tose šalyse jų yra laikomasi. Pavyzdžiui, atskleistų partijos rėmèjų sąrašus tokiose šalyse kaip Prancūzija, Italija ar Japonija jis pavadino „fantastikos kūriniais“ ir „ledkalnio viršūne“. Anot M. Pinto-Duschinsky, tai vyksta ir dèl įstatymų spragų, ir dèl politinès valios, galinčios priversti paklusti ịstatymams, trūku$\mathrm{mo}^{87}$. Analizuodami Ispanijos politini finansavimą Enrique García Viñuela ir Carmen González De Aguilar taip pat skeptiškai vertino naujų ístatymų galimybes užtikrinti skaidrumą ${ }^{88}$. Verta pridurti, kad Europoje teisinių politinio finansavimo aspektų tyrimai apima ne tik isstatymų poveiki, bet ir korupcijos problemą. Pavyzdžiui, Véronique

${ }^{85}$ Clift, Ben; Fisher, Justin. Comparative Party Finance Reform: The Cases of France and Britain. Party Politics. 2004, vol. 10, no. 6.

${ }^{86}$ Pelizzo, Riccardo. From Principle to Practice: Constitutional Principles and the Transformation of Party Finance in Germany and Italy. Comparative Party Politics. 2004, vol. 2, no. 2.

${ }^{87}$ Pinto-Duschinsky, Michael. Financing Politics: A Global View. Journal of Democracy. 2002, vol. 13, no. 4.

${ }^{88}$ Viñuela, Enrique García; Aguilar, Carmen González De. Reforming party finance in Spain. International Journal of Iberian Studies. 2011, vol. 24, no. 1. 
Pujas ir Martinas Rhodesas tyrė Italijos, Ispanijos ir Prancūzijos skandalų, susijusių su politiniu finansavimu, kilmę $e^{89}$, o Clay Clemensas gvildeno buvusio Vokietijos kanclerio Helmuto Kohlio politinio finansavimo skandalo aplinkybes ${ }^{90}$.

Lèšų įtaka rinkimų rezultatams. Europos šalyse mokslininkai tyrè ir kampanijų išlaidų ittaką rinkimų rezultatams. Ronaldas Johnas Johnstonas ir Charlesas J. Pattie išnagrinejjo Jungtinès Karalystès partijų išlaidas kampanijos laikotarpiu ir atskleidè, kad išlaidos gali svariai prisidèti prie rinkèjų palaikymo ${ }^{91}$. J. Fisheris, irgi analizavęs Jungtinès Karalystès atvejì, taip pat nustatè, kad didesnès išlaidos gali turèti teigiamą įtaką rinkimų rezultatams ${ }^{92}$. Nors atlikti tyrimai paliudijo ryši tarp kampanijos išlaidų dydžio ir pergalès rinkimuose tikimybès, svarbu pabrěžti, kad finansai čia nèra pergalę užtikrinantis veiksnys, nes rinkimų rezultatus lemia daug ịvairių faktorių.

Apibendrinant pažymètina, kad lèšu rinkimo tyrimai tapo vienu svarbiausių dėmenų politinio finansavimo tyrimų lauke Jungtinėse Valstijose, tačiau Europos šalyse tyrimų šia tema yra daug mažiau. Tokių tyrimų atlikta tik didesnèse šalyse, pavyzdžiui, J. Fisheris tyrè partijų vykdomo lèšų rinkimo tendencijas Jungtinejje Karalystejje ${ }^{93}$, o Achimas Goerresas ir Martinas Höpneris analizavo šias tendencijas Vokietijoje $^{94}$. Dažniausiai tokie tyrimai buvo orientuoti ị lèšų rinkimą

${ }^{89}$ Pujas, Véronique; Rhodes, Martin. Party finance and political scandal in Italy, Spain and France [interaktyvus]. West European Politics. 1999, vol. 22, no. 3.

${ }^{90}$ Clemens, Clay. A legacy reassessed: Helmut Kohl and the German party finance affair. German Politics. 2000, vol. 9, no. 2.

91 Johnston, R. J.; Pattie, C. J. The Impact of Spending on Party Constituency Campaigns at Recent British General Elections. Party Politics. 1995, vol. 1, no. 2.

92 Fisher, Justin. Party expenditure and electoral prospects: a national level analysis of Britain. Electoral Studies. 1999, vol. 18, no. 4.

${ }^{93}$ Fisher, Justin. Donations to political parties. Parliamentary affairs. 1997, vol. 50, no. 2 .

94 Goerres, Achim; Höpner, Martin. Polarizers or landscape groomers? An empirical analysis of party donations by the 100 largest German companies in 1984-2005. Socio-Economic Review. 2014, vol. 12, no. 3 . 
iš verslo organizacijų, o ne individualių rèmèjų. Be to, nėra tiriamos lèšų rinkimo internetu tendencijos ir galimybès. Tai lemia, kad tiek Europos šalyse, tiek kitose valstybėse šiuolaikiniai lèšų rinkimo tyrimai iš dalies prasilenkia su aktualijomis, kurias diktuoja Jungtinės Valstijos.

\section{Išvados}

Politinio finansavimo tyrimų tematika Jungtinèse Valstijose ir Europos šalyse turi ir bendrų bruožų, ir skirtumų. Ir ten, ir ten tyrinèjami naujai priimami isstatymai ir jų itaka politinio finansavimo sistemai, analizuojamas finansavimas per konkrečius rinkimus, taip pat ¿̇vairiose šalyse tiriamos partijų ir kandidatų finansavimo tendencijos bei galimybès - nuo lèšų rinkimo iš individualių aukotojų, verslo įmonių, profesinių sąjungų ar politinio veiksmo komitetų iki valstybès biudžete numatytų dotacijų partijoms. Tiek Jungtinių Valstijų, tiek Europos šalių tyrimų kryptis galima suskirstyti ị tris dalis. Jungtinėse Valstijose šios kryptys yra tokios: politinị finansavimą ir lèšų rinkimą reguliuojantys Jungtinių Valstijų ìstatymai, politinio veiksmo komitetų, renkančių lešas, veikla ir politinių lèšų rinkimas iš individualių aukotojų. Europoje yra tokios trys pagrindinès politinio finansavimo tyrimų kryptys: partijų finansavimo valstybės lèšomis ypatumai, politinị finansavimą ir lèšų rinkimą reguliuojantys ịstatymai bei lěšu įtaka rinkimų rezultatams.

Esminė politinio finansavimo tyrimų sritis, kurioje Europos šalys atsilieka nuo Jungtinių Valstijų, yra lèšų rinkimas iš individualių aukotojų, ypač pasitelkiant internetą, kaip komunikacijos priemonę lèšoms rinkti. Be abejo, šis atsilikimas mokslinių tyrimų lauke yra padiktuotas realių politikos skirtumų - tikètina, kad dar ilgai jokioje Europos šalyje partija ar kandidatas iš individualių rèmėjų nesurinks tokių isspūdingų sumų, kokias prieš 2008 ir 2012 metų prezidento rinkimus surinko B. Obama arba prieš 2016 metų prezidento rinkimus surinko Hillary Clinton. Nepaisant to, moksliniai Europos partijų ir kandidatų 
vykdomo lèšų rinkimo tyrimai galètų būti naudingi ne tik mokslo bendruomenei, bet ir pačioms partijoms, besitikinčioms ateityje surinkti daugiau lèšų iš individualių rèmèjų.

Tokie tyrimai būtų naudingi ir Lietuvai, kur lèšų rinkimas iki šiol nebuvo tirtas, nors politinio finansavimo tema mokslo darbus jau yra parengusios Ingrida Unikaite ${ }^{95}$ ir Elena Masnevaitè ${ }^{96},{ }^{97}$, o politikai lèšas renka ganètinai aktyviai. Lietuvoje prieš 2016 metų rudenị vykusius Seimo rinkimus daugiausia lèšu surinko Tẻvynės sąunga-Lietuvos krikščionys demokratai (152,7 tūkst. eurų fizinių asmenų aukų ir 4,1 tūkst. fizinių asmenų smulkių aukų), Liberalų sąjūdis (beveik 108 tūkst. eurų fizinių asmenų aukų ir 7,8 tūkst. eurų fizinių asmenų smulkių aukų) ir Lietuvos valstiečių ir žaliųjų sąjunga (103,6 tūkst. eurų fizinių asmenų aukų ir 259 eurai fizinių asmenų smulkių aukų), į šias sumas ịskaičiuotos ir atskirų partijų kandidatų surinktos lėšos. ${ }^{98}$ Lietuvos politinès partijos ir pavieniai kandidatai renka lèšas ir internetu - tokia veikla plètota ir per 2015 metų savivaldybių tarybų bei merų rinkimus, ir per 2016 metų Seimo rinkimus. Atsižvelgiant ị tai, kad Lietuvoje partijos deda pastangas rinkdamos lěšas ir jų surenka, ateityje šis politinio finansavimo aspektas turès būti išnagrinètas ir mūsų šalyje.

Jungtinių Valstijų ir Europos šalių mokslinès literatūros analizė taip pat atskleidè, kad trūksta mokslo darbų, kuriuose lèšų rinkimas būtų gvildenamas iš komunikacijos perspektyvos ir tiriamos partijų

${ }^{95}$ Unikaitè, Ingrida. Lithuania: Political Finance Regulations as a Tool of Political Manipulation. Public Finance and Post-Communist Party Development (red. ROPER, Steven; IKSTENS, Janis). Aldershot, 2008.

${ }^{96}$ Masnevaité, Elena. Parlamentinès veiklos finansavimas kaip netiesioginio valstybinio politinių partijų finansavimo forma. Parlamento studijos. Nr. 10 (2011).

${ }^{97}$ Masnevaitè, Elena. Nauja Lietuvos Respublikos politiniu partijų ir politinių kampanijų finansavimo bei finansavimo kontrolès ịstatymo redakcija - politinis impulsas ar būtinybé? Parlamento studijos. Nr. 11 (2011).

${ }^{98}$ Savarankiškų politinès kampanijos dalyvių politinès kampanijos finansavimo ataskaitų suvestinė. Vyriausioji rinkimų komisija, 2016. Prieiga per internetą: http:// www.vrk.lt/documents/10180/611100/2016-12-08+SPKD+PKFA+suvestine.pdf/ d4f37311-37c8-4f4a-818a-07df458972a9 [žiūrèta 2017 m. sausio 15 d.]. 
bei politikų galimybės pritraukti daugiau lèšų iš individualių aukotojų, ypač pasitelkiant interneto galimybes. Be to, trūksta kompleksinių tyrimų, kuriuose būtų išsamiai išanalizuoti visi lèšų rinkimo būdai: pradedant politikų komunikacijos internete veiksmais ir baigiant aukotojų motyvais. Lieka neatsakytas esminis klausimas - kaip ịvairiose šalyse žmonès, dalyvaujantys politinejje veikloje, gali efektyviai išnaudoti interneto komunikacijos kanalus lěšoms rinkti? Atsakymas ị ši klausimą yra svarbus Europai, kur daugelyje šalių ìstatymai nustato palankias sąlygas lěšoms rinkti, bet partijos ir politikai ne visada sèkmingai tuo pasinaudoja. 


\title{
MONEY IN POLITICS: ANALYSIS OF POLITICAL FINANCING TRENDS IN THE UNITED STATES AND EUROPE
}

\author{
Arnas Aleksandravičius
}

\section{Summary}

Keywords: political finance; political funds; campaign funds; political fundraising; campaign fundraising; regulation of political finance; donors of political parties; political parties.

In this article we analyze the legal regulation and scientific research on political finance in the United States and Europe. The aim is by analyzing the research on political fundraising carried out in the United States and Europe, to find out the main trends and lack of research. This analysis is relevant because it helps better understand the context of political finance in the United States and Europe, also to identify the trends and the need of future research. Moreover, the analysis and the introduction of topics of political finance research can become the basis of future research on political finance in the United States and Europe.

The analysis of legal regulation of political finance suggests that the laws on political finance in the United States and
European countries are often distinct, but in most cases the conditions for fundraising is good in both instances. The analysis of scientific research helped identify the main directions of the research in the United States and Europe. It was found out that the main research direction in which European countries fall behind the United States is fundraising from individual donors, and especially using internet as the channel of communication for fundraising. It was noticed that there is a lack of research analyzing fundraising from the perspective of communication, also analyzing the possibilities of improving fundraising mechanisms to raise more funds from individual donors, especially using the power of internet.

Iteikta 2017 m. vasario $7 \mathrm{~d}$. 